\title{
İktidarın Meşruiyeti ve Rıza Üretimi: Masallardan ve Mitlerden Kitle İletişimine Toplumsal Bilincin İnşası
}

DOI: 10.26466/opus.758822

*

\author{
Ahmet Öztekin*- Hülya Öztekin** \\ *Dr. Öğr. Üyesi, Erciyes Üniversitesi İletişim Fakültesi, Kayseri/Türkiye \\ E-Posta: aoztekin@outlook.com \\ ORCID: $\underline{0000-0001-7525-2788}$ \\ ** Dr. Öğr. Üyesi, Erciyes Üniversitesi İletişim Fakültesi, Kayseri/Türkiye \\ E-Posta: hoztekin@erciyes.edu.tr \\ ORCID: 0000-0003-4599-9906
}

\section{Öz}

Tarihsel süreçte bütün iktidar biçimleri, iktidarı ellerinde tutmak ve bunun sürekliliğini sağlamak adına verdikleri mücadelede meşru bir zemine dayanma ve yönetilenlerin rızasını kazanma ihtiyacı duymuşlar; bu ihtiyaçla farkl yöntem ve tekniklere başvurmuşlardır. Toplumsal bilincin ve hegemonyanın inşasına da hizmet eden bu yöntem ve teknikler, zaman içinde dönüşmüş ve biçim değiş̧irmiş olsalar da temelde aynı amaca hizmet etmişlerdir. Bu çalışma, sosyal ve siyasal yaşantıdaki güç ve iktidar ilişkileri çerçevesinde tarih boyunca iktidarların toplumsal bilinci inşa etmek ve riza üretmek üzere başvurdukları farklı yöntemleri ortaya koymayı amaçlamaktadır. Betimsel araştırma tasarımına sahip çalışma, ilkel topluluklardan modern kapitalist toplumlara kadar iktidarlar tarafindan kullanilan hegemonya ve riza üretim araçlarının tarihsel evrimine odaklanmakta; modern öncesi toplumlarda bu amaçla kullanılan masallar, mitler ve kutsal yalanların modern kitle iletişim araçlarıyla arasındaki ilişkiyi tartışmaktadır. Buna göre modern öncesi dönemde masalları ve mitleri yayan masalcllar, ozanlar ve destancıları yerini modern kapitalist toplumlarda kitle iletişim araçları almıştır. Modern ya da teknolojik masalcılar olarak adlandırabileceğimiz kitle iletişim araçları modern masalların ve mitlerin hem üreticisi hem de dağıtıcısı konumundadırlar. Söz konusu modern masallar ve mitler çoğu zaman 'gerçeklik' iddiasıyla sunulmakta, iktidarın yapısı ve sistemin doğası maskelenmektedir.

Anahtar Kelimeler: İktidar, meşruiyet, hegemonya, rıza üretimi, toplumsal bilincin inşası. 


\title{
Legitimacy of Power and Consent Manufacturing: Construction of Social Consciousness From Tales and Myths to Mass Communication
}

\begin{abstract}
In the historical process, all forms of power needed to stand on a legitimate basis and gain the consent of the ruled in their struggle to keep power in their hands and to ensure its continuity; and they have resorted to different methods and techniques within the scope of this need. Even if these methods and techniques, which also serve to construction of social consciousness and social hegemony, were transformed, and changed their shapes over time, they basically served the same purpose. This study aims to present the different methods that the powers have used in order to construction of social consciousness and consent manufacturing throughout history within the framework of power relations in social and political life. The study, with a descriptive research design, focused on the hegemony and consent manufacturing tools used by the powers, starting from primitive communities to modern capitalist societies, within the context of their historical evolution; and discusses the relationship between tales, myths and noble lies used for this purpose in pre-modern societies with modern mass media. According to this, mass media in modern capitalist societies replaced storytellers and poets who spread tales and myths in the pre-modern period. Mass media, which we can call modern or technological storytellers, are both producers and distributors of modern tales and myths. These modern tales and myths are often presented with the claim of 'reality', the structure of the power and the nature of the system are masked.
\end{abstract}

Keywords: Power, legitimacy, hegemony, consent manufacturing, construction of social consciouness 


\section{Giriş}

Sosyal bir canlı olarak yaşamını bir toplum içerisinde o toplumun bir parçası olarak geçirmeyi tercih eden insanoğlu, ürettiği ortak ekonomik, kültürel, sosyal değerlerle toplumsal birliktelikler kurmaktadır. Bireyin iletişime, etkileşime geçtiği an itibariyle başlayan bu toplumsallaşma ve toplumsal örgütlenme süreci, ilkel topluluklardan günümüz modern toplumlarına kadar sürekli bir değişim ve gelişim çizgisinde ilerlemiştir. Illkel topluluklar hızlı nüfus artışı, üretim ilişkileri, siyasallaşma gibi pek çok faktör tarafından etkilenerek kitlelere dönüşmüştür. Bu dönüşüm sonrası kitle ve kitlelere ilişkin örgütlenme, iş birliği, iş bölümü gibi yönetsel konular çok yönlü yapısal bir yönetim olgusunu gerekli kılmış ve modern yönetsel organizasyonların temelleri atılmıştır. Bu anlamda toplumsallaşmayla, siyasallaşma aslında büyük ölçüde birbirine benzemektedir. Toplumsal olanın siyasal olanı bilinç dışı olarak kendi içinde barındırdığını belirten Arendt (1994, s.41-53), Latince kökenli olan societas kelimesinin sınırlı olmakla birlikte, insanların başkaların yönetmesi veya özel bir amaç çevresinde bir ittifakın kurulması gibi açık bir siyasal anlama da sahip olduğunu ifade etmektedir. Modern dünyada toplumsal alan ile siyasal alan arasındaki mesafenin, antik dünyaya göre çok daha az olduğunun altını çizen Arendt, siyaseti toplumun bir işlevi olarak değerlendirmektedir.

İnsanlığın toplumsallaşma, diğer bir deyişle siyasallaşma süreci, zamanla kurumsallaşan bazı yapıların doğmasına neden olmuştur. Kültürlere ve toplumlara göre farklı isimlerle anılsalar da bütün bu örgütlenme biçimleri bir güç-iktidar ilişkisi kurarak, yöneten-yönetilen ayrımını ortaya çıkarmıştır. Söz konusu bu ayrım, toplumsal yapıya ve döneme göre değişen özellikler göstermekle birlikte çok değişkenli bu yapının tek değişmeyeni olan 'iktidar mücadeleleri', tarih boyunca farklı şekillerde sürmüştür.

İktidar mücadelesi, iktidar olmak için sadece bir kez girişilen bir çaba değildir. Bu mücadele, iktidardayken iktidarı sürdürebilmek, iktidarı koruyabilmek adına iktidar kaybedilene kadar devam edilen; iktidar kaybedildiğinde ise yeniden kazanılması için tekrar edilen sonsuz sayıda girişim gerektiren döngüsel bir süreçtir. İktidarın ele geçirilme çabası, asla yok edil(e)meyen ama uygun koşullar ortaya çıkana kadar ertelenebilen, saklanabilen içgüdüsel bir arzunun sonucudur. 
İktidarın meşruiyet kazanarak büründüğü kimlik olan otorite, insanların hem korktukları hem de ihtiyaç duydukları yönetsel bir yapı olarak karşımıza çıkmaktadır. Sennett'e göre (2005, s. 11-27) sadakat, otorite ve kardeşlik bağları olmaksızın, bir bütün olarak hiçbir toplum ve bu toplumun hiçbir kurumu uzun süre işlevselliğini koruyamamaktadır. Bu nedenle otorite, toplumlar için temel bir gereksinimdir. Bu çerçevede kitleler bir yandan çobanından vazgeçemeyen bir sürüyken (Le Bon, 1997, 106), diğer yandan ise kurallar koyan ve sınırlar çizen bir otorite kavramının çok da cazip gelmediğini söylemek mümkündür.

İktidar olabilmek ya da mevcut iktidarı koruyabilmek, Lippmann'ın (1998) 'büyük güruh' olarak tanımladığı kitleden korunmaya ya da kitlenin rızasını almaya bağlanmıştır. İlk toplumsal yapılarla birlikte iktidarların kitleleri sürekli gözetlemesi, kitlelerin de iktidara olan güvenleri ve rızaları önemli bir yönetim sorunsalını oluşturmuştur. Bu nedenle, güçle birleşen hükmetme arzusunun bir sonucu olarak ortaya çıan iktidarın, kitleleri manipüle etme çabası da iktidarın tarihi kadar eski ve iktidar kadar tartışılagelmiş konular arasında yer almaktadır.

Kitleler, güçleri nedeniyle iktidarlar tarafından sürekli potansiyel bir tehdit olarak görülmüş, kitleleri kontrol altında tutmak ve kitleleri ikna etmek siyasal iktidarın temel amaçları arasında yer almıştır. Toplumsal kültürün araçsallaşmış bir tezahürü olarak ortaya çıkan iktidarlar, toplumun her bireyinden itaat beklemektedir. Kitleler üzerindeki söz konusu denetimin temel amacı da bireylerin kontrolünün ve itaatin sağlanmasıdır. Bu nedenle demokrasi dahil bütün siyasal sistemler, bireylerin itaatini sağlamak ve bu doğrultuda kitleleri manipüle etmek üzerine kurulmuştur. Althusser 'devletin ideolojik aygitları', Gramsci de 'hegemonya' kavramiyla gücün iktidar kurabilmesi ya da iktidarını sürdürebilmesi sürecinde ideolojik olarak toplumsal rıza üretimi üzerine benzer değerlendirmelerde bulunmuşlardır.

Bu çalışma, sosyal ve siyasal yaşantıdaki güç ve iktidar ilişkileri çerçevesinde tarih boyunca iktidarların toplumsal bilinci inşa etmek ve rıza üretmek üzere başvurdukları farklı yöntemleri ortaya koymayı amaçlamaktadır. $\mathrm{Bu}$ çerçevede çalışma, ilkel topluluklardan günümüz modern kapitalist toplumlarına kadar iktidarlar tarafından kullanılan hegemonya ve rıza üretim araçlarının tarihsel evrimine odaklanmakta; modern öncesi toplumlarda hegemonya ve rıza üretim aracı olarak kullanılan masallar, mitler, efsaneler ve 
kutsal yalanların işlevsel olarak modern dünyadaki karşılıkları olan kitle iletişim araçlarıyla arasındaki ilişkiye değinmektedir. Toplumsal bilincin inşası ve rızanın imalatına yönelik manipülasyon faaliyetlerinin ortaya çıkışına ilişkin modern yaklaşımlar, tarihsel olarak sanayi devrimi sonrasını ve özellikle 20. yüzyılı işaret etmekte; bu kavramları kitle iletişim araçlarının ortaya çıkışıyla ilişkilendirmektedirler (Freire, 1993; Lippmann, 1998, Bernays, 1947, Lasswell, 1927). Bu çalışma ise bahsi geçen yaklaşımlardan farklı olarak yöneten-yönetilen ilişkisinin olduğu her yerde ve her dönemde iktidarların kendi meşruiyetlerini ve sürekliliklerini sağlamak adına zihinleri yönlendirmek ve kamuoyunu manipüle etmek suretiyle hegemonya ve rıza üretimi çabası taşıdıkları; dolayısıyla söz konusu çabanın sadece modern kapitalist toplumlara özgü olmadığı iddiası üzerine yapılandırılmıştır.

\section{İktidar ve İktidarın Meşruiyeti}

Birlikte yaşamanın doğal bir sonucu olarak ortaya çkan iktidar kavramı, toplumsal hayatın ve toplumsal ilişkilerin bütün biçimlerine içkindir. İktidar, gündelik ya da politik konuşmalarda sıklıkla kullanılan ama tanımlanması da bir o kadar zor ve karmaşık bir kavramdır. Bu zorluk, kavramın doğasından kaynaklanmaktadır. İktidarı aşka benzeten Nye (1990, s. 177), onu deneyimlemenin tanımlamaktan ya da ölçmekten daha kolay olduğunu ifade etmektedir.

İktidarı tanımlamaya yönelik çok sayıda yaklaşım bulunmaktadır. İktidar olma çabasını, temel insani güdülerden biri olarak gören Russell'a göre (2003) 'iktidar', sosyolojinin anahtar kavramıdır. Sosyolojik bir kavram olarak iktidar en geniş kapsamıyla, kendi iradesiyle istediği eylemi gerçekleştirebilen ve başka insanların göstereceği dirençten etkilenmeyen (Mills, 1974, s. 15-16); kendi amaç ve çıkarlarını koruyarak, olayların seyrine müdahale ederek sonuçlarına tesir edebilen (Thompson, 2008, s. 29); başka bireyler üzerinde hakimiyet kurarak (Russell, 2003), kendi iradesini onun üzerinde egemen k1lıp, bir şey yapmaya ya da yapmamaya zorlayabilme gücüne sahip olarak (Kışlalı, 1997, 102), toplumsal ilişki içerisinde bulunan birinin diğerlerinden buyruklarına uymaların talep edebilme hakkı (Duverger, 1982, s. 190) olarak tanımlanabilir. İktidar olmak, sahip olduğu güçle, bir sosyal ilişki içinde, bir aktörün hangi temele dayanırsa dayansın, direnmeyle karşılaşsa bile istedi- 
ğini yapabilme konumunda olmak ve bu şekilde inşa edilen egemenlikle, belirli içerikteki bir emre, belirli bir grup insanın itaat etme ihtimali olarak ele alınmaktadır (Weber, 2008, s. 28-29).

Russell gibi iktidarı, toplumun her kademesinde farklı şekillerde karşımıza çıkabilecek sosyolojik bir kavram olarak tanımlayan diğer bir düşünür de Foucault'dur. Foucault (2007, s. 111-162) iktidarın, bir babanın karısı ve çocukları üzerindeki hakimiyetinden doktorun hastası üzerindeki inisiyatifine, eşraftan kişilerin kendi iradelerini toplumun geneli üzerinde egemen kılmasından, patronun fabrikasındaki işçiler üzerinde uyguladığı zorlayabilme gücüne kadar farklı şekillerde gözlemlenebileceğini belirtmektedir. Bu çerçevede Foucault'ya göre (2014, s. 73-74) iktidar, bir öteki olarak öznelerin üzerinden ziyade öznelerin eylemleri üzerinde mutlak bir etkiye sahip olma durumudur. İktidar, doğrudan ve aracısız olarak özneler üzerinde eylem yapabilme gücünü elinde tutarak bu gücüyle zorlayıcı, bükücü, işkence uygulayıcı, tahrip edici şiddet unsurlarını kullanabilmektedir. Bütün bunlar iktidara, iktidarın içinden çıktı̆̆ toplumsal yapıya ve iktidarın egemen olduğu sosyal yapıya göre değişiklikler gösterebilmektedir. Bu değişikliklerse iktidar mücadelelerinin faktörlerini, bu mücadelenin içinde yaşandığ 1 toplumun kurumlarının, adetlerinin, geleneklerinin, zihniyetlerinin, inançlarının, kolektif tasarımlarının tümü yani o toplumun kültürü olarak tezahür etmektedir (Duverger, 1964, s. 92).

Her ne kadar toplumdan topluma, kültürden kültüre değişiklik gösterse de iktidar, hapsetmek, öldürmek gibi bireylerin bedenleri üzerine doğrudan doğruya güç uygulayarak; iş vermek veya işsiz bırakmak gibi kandırma ve belli bir yöne sevk etme aracı olarak mükâfat ya da cezayı kullanarak ya da en geniş anlamiyla propaganda gibi fikirlerini etkileyerek bireyleri etkisi altına alabilmektedir (Russell, 2003, s. 38). Bu çerçevede ordu ve polis, beden üzerinde zorlayıcı güç uygulayan iktidar odakları; ekonomik yapılar ve örgütler, ödüller ve cezalarla etkileyen iktidar odakları; okullar, kiliseler ve siyasi partiler de düşünceleri etkileyen iktidar odakları şeklinde karşımıza çımaktadır. Ne var ki, bu sınırlandırmada her iktidar odağı, en karakteristik gücünün yanı sıra başka güç biçimleri de uyguladığı için aralarındaki ayrımlar kesin çizgilerle ayrılamamaktadır.

Her karmaşık toplumda iktidar, teşkilatlanmıştır. Politik rejimler de iktidarın teşkilatlanışının çeşitli tipleridir. Bunlar hem anayasaların, kanunların ve genel olarak hukuki metinlerin kurdukları şekli ve resmî kurumlardan 
hem de olayların, alışkanlıkların, törelerin, adetlerin, usullerin meydana getirdikleri kurumlardan doğmaktadırlar (Duverger, 1964, s. 92). Bu kurumlardan biri olarak sayılabilecek iktidar anlamındaki devlet de kendi toplumundaki belirli dahili iktidar yapılarının çıkarları doğrultusunda hareket eden iktidar araçlarından biri olarak tanımlanmaktadır (Chomsky, 2010, s. 196).

İktidar kavramı çoğunlukla 'güç' kavramıyla birlikte, hatta bazen eşanlamlı kullanılmaktadır. Güç, kendisine zaman tanıdığında iktidar haline gelmekte; ama kriz anı, geri dönüşsüz karar anı gelince güç çıplak güç haline geri dönmektedir. Dolayısıyla güçten daha geniş bir uzam üzerinde işleyen iktidar daha geneldir ve güce göre çok daha fazlasını içerir, ama daha az dinamiktir. İktidar daha törenseldir, hatta belirli bir sabır ölçüsü bulunmaktadır (Canetti, 2006, s. 283-284). Güç ve iktidar ilişkisinde gücün iktidara içkin olduğunu ancak iktidarın salt güce indirgenemeyeceğini anlamak gerekmektedir. İktidar, gücü kullanır, dönüştürür ve bünyesinde barındırır (Satır, 2018, s. 116). Bu bağlamda her ne kadar her güç ilişkisi, her an bir iktidar ilişkisi içerse de (Foucault, 2007, s. 112) "güç, tek başına siyasal iktidarın egemenlik şartı değildir. Güç, sadece siyasal iktidarın var oluşunu sağlamaktadır. Siyasal iktidarın temel sorunu olan 'süreklilik' ise ancak eşitsiz güç ilişkilerinin her durumda devam ettirilmesi ile çözülebilmektedir" (Çetin, 2003, 83-84).

İktidarın elinde bulundurduğu güç ve buyurma imkanının cazibesi, iktidarların dışında iktidarın imkanlarından faydalanmak isteyen bazı kişi ya da grupların da ortaya çıkmasına neden olmuştur. Bu grupları 'iktidar seçkinleri' olarak adlandıran Mills (1974), her iktidarın çevresinde bu tür yapılanmaların olduğundan bahsetmektedir. İktidar seçkinlerini kısaca "toplum için önemli sonuçlara yol açabilecek nitelikteki kararları alabilen kimseler" olarak tanımlayan Mills, çağdaş kapitalist sanayi toplumunun, büyük sanayi kapitalistler, üst düzey politikacılar ve askeri yöneticilerden oluşan bir seçkinler takımı tarafından yönetildiğini; bu kliğin içindeki gerçek iktidarın ise sanayi alanında yer alan sermayelerde bulunduğunu iddia etmektedir. İktidar seçkinlerini, liderlerin emirlerine itaat etmeye alışmıs ve elde ettiği faydalar nedeniyle egemenliğin devamında kişisel çıkarları olan insanlar olarak gören Weber (2012, s. 318), bu yapının kendi aralarında egemenliğin devamına hizmet edecek işlevlerin icrasına bölündüğünü belirterek, bu insanların mevcut iktidar çıarlarının icrası için sürekli hazır tutulduklarını belirtmektedir. Ordu/bürokrat, burjuva ve aristokrasinin, toplumları asıl yöneten yapılar ol- 
duğunu iddia eden Marx (2009a) ise 1850'lerde Fransa'daki burjuva ve aristokrat sınıfların, iktidarlarını sağlamlaştırmak için ideolojik temsilcilerle, sözcülerle, siyaset bilginleriyle ve avukatlarla birlikte çalıştıklarını belirtmekte$\operatorname{dir}$ (Marx, 2009b, s. 12).

İktidara ilişkin temel sorunların başında iktidarın kaynağı ve meşruiyeti gelmektedir. Yönetenle yönetilen arasındaki ilişkiyi en basit haliyle güç ve iktidar ilişkisi olarak kabul etmek, söz konusu ilişkinin sosyal, siyasal, ekonomik, kültürel, psikolojik ve iletişimsel boyutları olduğunu da kabul etmek anlamına gelmektedir. Bu anlamda iktidar kavramı, bireyin etrafını çepeçevre saran, tüm yaşamını kuşatan geniş bir çerçeveyi oluşturmaktadır. Bu çerçevede iktidarın meşruiyeti, yönetenlerin yönetme gücünün kaynağını nereden aldığı, bu gücün bir hak olup olmadığı, yönetenlere neden itaat edildiği gibi soruların cevaplarına dayanmaktadır.

Tarih boyunca iktidarların meşruiyeti ve meşruiyetin kökenine dair çeşitli teorilerin öne sürüldüğü bilinmektedir. İlk dönemlerde meşruiyetin temeli gökyüzünde, tanrıda ve kutsal kitaplarda aranmıştır (Kapani, 1998, s. 68; Duverger, 1982, s. 194). Teokratik temelli bu düşünceler, etkinliklerini ancak 18. yüzyılın ortalarına kadar koruyabilmişlerdir. Aynı yüzyıl içinde ortaya çıkan yeni fikir akımları meşruiyeti eskiden olduğu gibi soyut temellerde aramak yerine daha somut olan yeryüzünde yani içinde vücut bulduğu toplumda aramaya başlamıştır (Kapani, 1998, 70-71). Özellikle günümüz toplumlarında iktidar ve meşruiyet arasındaki ilişki daha fazla sorgulanan ve tartışlan bir ilişki haline gelmiştir. Bu nedenle iktidarların meşruiyetini kurabilmesi öncelikli olarak toplumsal rızanın üretimini zorunlu kılmıştır.

İktidarın temelinde yatan olgu, toplumdaki tüm grupların, açık ya da kapalı şekilde yöneticilerinin varlığını kabullenmiş ve onların emir verme hakkını tanıyarak onlara rıza göstermiş olmalarıdır (Duverger, 1982, s. 183). Bu anlamda toplum tarafından emir verme hakkı tanınmayan yani rıza gösterilmeyen iktidarların, iktidarı ellerinde tutmakta ciddi sorunlarla karşılaştıkları bilinmektedir. Sonuç olarak bir iktidarın ortaya çıkması ya da sürekliliğini sağlaması meşruiyetine; meşruiyeti de toplumda meşru olduğuna ilişkin bir fikir birlikteliğine bağlıdır. Yani iktidarlar meşruiyetlerini inşa edebildikleri ve bu meşruiyetlerini koruyabildikleri sürece iktidar olmaya devam edebilmektedirler. Bu anlamda Kapani (1998, s. 67), sadece fiziksel gücün ve kaba kuvvetin iktidarları uzun süre ayakta tutamadığını belirterek, iktidarı ellerinde bulunduran grupların, sadece halka emretme ve yönetme gücüne değil 
aynı zamanda emretme ve yönetme hakkına da sahip olduğuna halkı inandırmaya çalıştığının altını çizmektedir. Bu doğrultuda iktidarın halka, egemenliğinin rastgele değil belirli bir hakka dayandığı fikrini aşılayarak kendi iktidarının meşruiyetini inşa edebileceğinden bahseden Kapani, iktidarın çabaları sonucunda meşruiyet kazanıldığında ise yönetilenler için itaatin bir görev haline geleceğini vurgulamaktadır.

Herhangi bir iktidarı, iktidar yapan şey onun meşruluğudur (Duverger, 1982, s. 183-188). Dolayısıyla her iktidar, iktidarını sürdürebilmek için meşruiyetin ilkelerine başvurarak kendini haklılaştırmaya mecburdur (Weber, 2012, s. 319). Meşruluk ve otoriteyi birbirine özdeş olarak gören Weber, insanların yetkisinin meşru olmadığını düşündükleri bir iktidara, kişi ya da kurumlara itaat etmeyeceğini ifade ederek, toplumdaki otorite duygusunun, insanların yöneticilerine 'gönüllü olarak' itaat ettiklerinde var olacağını savunmaktadır (Sennett, 2005, s. 30). Bu anlamda iktidarın meşruluğu, iktidarın topluluk üyeleri ya da hiç değilse, bunların çoğunluğu tarafından, bir iktidar olarak tanınmasıyla ortaya çıkmaktadır (Duverger, 1982, s. 194).

Meşruiyet, sadece bir kez inşa edilen ve tamamlanan bir süreç değildir. Sürekli yeniden inşa edilmesi gereken bir olgudur. Meşruiyet, birey, toplum ve siyasal iktidar arasındaki ilişkilerin üzerinde temellendiği ilkeleri, kanunları ve değerleri göstermektedir. Meşruiyet, bireyin, toplumun ve siyasal iktidarın bağlı kaldığı bir üst sözleşme olarak düşünüldüğünde bütün tarafların da karşılıklı uzlaşı üzerinde birleşmesini sağlamaktadır. Fakat, siyasal iktidarın gücüne dayanarak bu karşılıklılığı tek taraflılığa dönüştürebilme gücünün riski, meşruiyet sorununun/krizinin en can alıcı yönünü oluşturmaktadır. Günümüzde, siyasal iktidarın sürekliliği sorununun çözümü için ortaya atılan modern söylem, 'toplumsal sözleşme' olarak karşımıza çıkmaktadır (Çetin, 2003, s. 83-84).

Toplum sözleşmesi teorileri ile devlet, toplum ve birey olmak üzere siyasal iktidar ilişkilerinin üzerine oturduğu üç temel alan, üç meşruiyet kaynağ ortaya çıkmıştır. Bu üç meşruiyet kaynağının temellendiği üç meşruiyet ilkesi de 'güvenlik', 'eşitlik' ve 'özgürlük'tür. Modern siyasal iktidarlar, meşruiyetlerinin kaynağını bu üç olgudan birine dayandırmaktadırlar. Siyasal iktidarlara rasyonel meşruiyet kaynaklarının arandığı modern devlet teorilerinde, bu üç olgunun esas alındığı kuramlarla karşılaşılmaktadır. Özellikle toplum sözleşmesinin meşruiyeti bağlamında bu üç unsura dayanan arayışlar söz konusudur. Devleti, toplum sözleşmesinin merkezine koyan Hobbes için 
meşruiyet, güvenlik demektir. Güvenlik kaynağına dayalı meşruiyet arayışının yol açtığı devlet modelleri de doğal olarak otoriter ve totaliter bir kimlik almaktadır. Rousseau ise toplum sözleşmesi kuramında devletin meşruiyetini topluma dayandırmakta ve eşitlik anlayışını temel alan bu argümanda toplumun tümünü temsil eden genel irade ile siyasal iktidarı özdeşleştirmektedir. Devlet toplum, toplum da devlet olmaktadır. Toplumsal ve siyasal eşitliği ve özdeşliği bozacak her türlü olgu, genel iradenin mutlaklığının meşruiyeti gereği sistemin dışına itilmektedir. Bireyi ve bireysel hakları toplum sözleşmesinin merkezine oturtan Locke ise güvenlik ve eşitlik yerine özgürlük arayışını meşruiyetin kaynağı olarak kabul etmektedir. Locke'a göre, doğal haklar ve özgürlükler tüm siyasal iktidar ilişkilerinin meşruiyet gerekçesidir ve bunlardan kaynaklanmayan hiçbir hak ve yetki siyasal iktidar adına kullanılamaz. Özgürlüğe dayalı devlet gelişiminin temel argümanı olan bu meşruiyet arayışı liberal ve demokratik devlet geleneklerinin temel ilkesi haline gelmiştir (Çetin, 2003, s. 73).

"Modern meşruiyet arayışını siyasal iktidarın güçlü, mutlak ve bölünmez olması gerektiği üzerine kuran Machiavelli ve Hobbes, devleti ve devlet kaynaklı meşruiyeti savunan ilk kurucu meşruiyet düşünürleridir. Machiavelli ile güç, başarı ve güvenliğin öncelendiği yeni bir insan, yeni bir toplum anlayışına dayanan yeni bir iktidar ve meşruiyet geleneği kurulmuştur. Dinsel meşruiyetin ve toplumsal tabakalaşmanın modern iktidarın egemenlik söylemindeki birlik, bütünlük ve mutlaklık anlayışını parçalayan üstünlüğü reddedilerek 'tek' bir iktidar ve meşruiyet söylemi ortaya çıkmıştır' (Çetin, 2003, s. 74). İktidarı ele alırken tamamen pratik düzeyde ve gücü merkeze alarak tanım ve tespitlerde bulunan Machiavelli (1994, s. 69), iktidarı bir, bütün, mutlak ve sınırsız olarak görmekte ve iktidarı korkunun üzerinde yükselen bir güç kullanma aracı olarak ele almaktadır. Machiavelli'ye göre iktidarın kazanılmasında ve sürdürülmesinde her yol mubahtır. İktidarın halk üzerinde meşruiyetini inşa etmesinin bir zorunluluk olduğunu "Prens her zaman aynı halkla yaşamak zorundadır" hatırlatmasıyla yapan Machiavelli (1994, s. 77), bu durumun gerekçesini de büyük güçlerden kendi iktidarına yönelik düşmanlıklara karşı halkın desteğinin sürdürülmesindeki mecburiyet olarak açıklamaktadır. Benzer şekilde Rousseau da (2005, s. 113) halkın desteğini hep önemsemiş ve en büyük gücü halkların sevgisinden kaynaklanan güç olarak görmüştür. Ancak bu gücün geçici ve koşullara bağlı oldu- 
ğunu da belirten Rousseau, iktidarların bu gücü tek başına yeterli görmeyeceklerini ve asla onunla yetinmeyerek, iktidarlarının mutlaklığını ve kişisel çıkarlarının halkın iktidara direnemeyecek kadar zayıf, sefil olmasında yattığını vurgulamaktadır.

Kurucu meşruiyet teorilerinin önemli ilkelerinden olan güvenlik kaygısı ve kaos korkusuna en fazla dikkati çeken düşünürlerden biri olarak Hobbes'un (2017) devlet düşüncesinde iktidar, meşruiyetini bireysel güvenlik ihtiyacından almakta ve iktidarın meşruiyete olan mecburiyeti de sürdürülebilir bir güç isteğinden kaynaklanmaktadır. Meşruiyetin sağlanamadığı tersi durumlarda ise iktidarların hem yönetim araçlarını kullanmalarında hem de toplumsal anlamda itaat sorunları yaşayarak iktidarı her an kaybetme tehlikesi bulunmaktadır. Hobbes, egemen güç yokluğunu tam bir kaos, kargaşa ve savaş durumu olarak tasvir etmekte ve bir toplum sözleşmesi olarak Leviathan' 1 işaret etmektedir. Hobbes'un toplumsal rıza ve katılıma dayalı meşruiyet/sözleşme anlayışı egemenin yaratılmasıyla son bularak, 'meşruiyetin sürekliliği' yerini 'iktidarın sürekliliği'ne bırakmaktadır. Toplumsal rıza da yerini güvenlik korkusuyla yok edilmiş bireylerin mutlak itaatine bırakmaktadır. Bireylerin tüm hak ve özgürlüklerinden vazgeçtikleri toplum sözleşmesi bir kulluk ve boyun eğiş anlaşmasına dönüşmektedir. Bu aşamadan sonra birey ve bireysel hak ve özgürlükler yok edilmekte ve tek tek görevler siralanmaktadır. Uyrukların artık kendilerine özgü düşünceleri, iradeleri ve eylemleri yoktur. Toplumsal irade siyasal iktidarın iradesinde eriyerek yok olmakta, egemenin iradesi ise mutlak ve kutsal egemenin dişında ya da üstünde hiçbir güç bulunmayana kadar sınırsızlaşmaktadır. Bu gücün parçalanmasını düşünmek ise imkânsız hale gelmektedir (Çetin, 2003, s. 76).

Weber (2008, s. 40), meşruiyetin dayanakları ve meşru otoritenin yapısını rasyonel, geleneksel ve karizmatik olmak üzere üç başlık altında ele almaktadır. Rasyonel temeller, egemen konumdaki iktidarların emir verme hakkına sahip olduğu kabulüne dayanarak yasal otoriteye işaret ederken, geleneksel temeller de eski dönemlerden beri var olan gelenekler ve kutsal inanışlar çerçevesinde otoritenin meşru olduğuna dair bir inancı beslemektedir. Karizmatik temeller ise bireyin kişisel özellikleri, kahramanlığı ve istisnai olma durumuna dayalıdır ve karizmatik otorite olarak adlandırılmaktadır. Bu üç temel dayanak noktası bir siyasal iktidarın meşruiyetini belirlemektedir. Bu noktada Duverger (1982, s. 194), meşruluğun 'kökenleri' olarak adlandırılan ge- 
lenek, karizma ve yasanın aslında birer ussallaştırma ve aklamadan ibaret olduğunu, iktidarın tek kaynağının, o iktidarın uygulandığı topluluğun norm ve değerler sistemince saptanan meşruluk şemasına uygunluğu ve bu şema konusunda da o toplulukta bir görüş birliğinin bulunmasında yattığını iddia etmektedir.

Meşruiyet, hangi dayanak noktalarından sağlanırsa sağlansın, iktidarların varlık koşullarından biri olarak kabul edilmektedir. Meşruiyetini yitiren bir iktidarın toplumdaki varlığı tartışmalı hale gelir ve yönetilen kesim tarafından kabul görmez. Dolayısıyla iktidarlar, meşruiyetlerini yineleyerek güncel tutmak istemektedirler (Satır, 2018, s. 121). Bu noktada ideoloji, hegemonya ve rıza üretimi gibi kavramlar, iktidarların meşruiyet sağlama çabalarının bir parçası olarak ortaya çıkmaktadırlar.

\section{İdeoloji, Hegemonya ve Rıza Üretimi}

Kültürel etkenlerin siyasal yaşamdaki yansıması söz konusu olduğunda, akla ilk gelen olgu kuşkusuz ideolojilerdir. İdeolojiler, toplumda benzer koşulları paylaşanların, bu koşullardan doğan ortak gereksinmelerini karşılayan, kendi içinde tutarlı inanç sistemleri olarak tanımlanmaktadır. İdeolojiler, ilgili toplum kesimlerinin doğru ya da yanlış bilinçlenmesinde, siyasal çatı̧̧maların yönlendirilmesinde önemli rol oynamaktadırlar. Her ideolojik çatışma, genellikle belirli toplum kesimlerinin çıkarları arasındaki bir çatışmadan kaynaklanmaktadır (Kışlalı, 1997, s. 111). Bu bağlamda her sınıf ya da toplumsal kategorinin kendi ideolojisini politik savaş içerisinde yarattı̆̆ını ifade eden Duverger (1964, s. 12-91), iktidarın da anlaşmazlıkları yatıştırmak ve birleşmeyi sağlamak amacıyla kendi ideolojisini geliştirdiğini, bunun sonucunda da politik savaş biçimlerinin başlıca kurumlardan, ideolojilerden, değer sistemlerinden ve kolektif tasarımlardan ibaret olduğunu savunmaktadır. Dolayısıyla bir ideoloji tarafından ele geçirilen devlet aracı, iktidar için söz konusu kurumlardan en önemlisi durumundadır.

Devletin, iktidarın tesis etme ve devam ettirmede 'devletin baskı aygitları' ve 'devletin ideolojik aygıtlanı' şeklinde iki tip aygıtı kullandığını söyleyen Althusser (2014, s. 50-51), söz konusu baskı aygıtlarını hükûmet, idare, ordu, polis, mahkemeler, hapishaneler vb. kurumlar olarak ifade ederken, ideolojik aygitları ise dini kurumlar, okul, aile, hukuk, siyasal partiler, sendikalar, medya ve kültürel yapılar olarak ele almaktadır. Althusser, bireylerin 
karşısına bu şekilde birbirinden ayrı ama uzmanlaşmış kurumlar biçiminde dolaysız olarak çıkan belirli yapılardan bahsederek devleti, egemen sınıfın devleti olarak tanımlamaktadır.

İdeoloji kavramı, kullanılmaya başlandığı ilk dönemde, 'fikirler bilimi', 'fikirlerin çözümlenmesi', 'fikirlerin kökeninin araştırılması' anlamında kullanılmıştır (Gramsci, 2008, s. 208). Bu kavramın daha sonraki kullanımına bakıldığında ise bir insanın ya da bir toplumsal grubun zihninde egemen olan fikirler, tasarımlar sistemi olarak ele alındığı görülmektedir (Althusser, 2014; Duverger, 1964, s. 81-82). İdeolojiyi, iletişim içinde ifade edilen bir fikirler sistemi olarak gören Lull (2001, s. 19), bu fikirler sistemini, bilinç gruplar ya da bireyler tarafından taşınan duygular, kanılar, tutumlar toplamının temeli olarak değerlendirmektedir. İdeolojiyi, bir sınıfın diğerine kabul ettirdiği fikirler dizgesinden çok, tüm sınıfların katıldığı süregiden ve her yana yayılmış pratikler dizgesi olarak ele alan Althusser, devletin ideolojik aygitlarının bu süreğenliği ve yayılmayı sağladığını belirtirken, azınlığın çoğunluk üzerindeki iktidarın baskıcı olmayan bu araçlarla sürdürdügünü ifade etmektedir. İdeolojiyi, yönetici sınıfın fikirlerinin toplumda doğal ve normal görünmesini sağlayan bir araç olarak tanımlayan Marx ise her çağın egemen düşüncelerinin, o çağın egemen sınıfının düşünceleri olduğunu belirterek iktidar ve ideoloji ilişkisine vurgu yapmaktadır (Fiske, 1996, s. 221-224).

Egemen ideolojinin dolayısıyla da iktidarın yeniden üretimi, basit bir tekrar, basit bir yeniden üretim değildir. Bu yeniden üretim aslında önceki ideolojik unsurların, sınıf mücadelesi içinde yeni karşıt eğilimlere ve önceki biçimlere karşı yenilenmesidir. Egemen ideolojinin yeniden üretimi yolunda verilen mücadele hiçbir zaman bitmiş, tamamlanmış sayılamaz (Althusser, 2014, s. 12-13). Sürekliliğe ve bu sürekliliği sağlayacak araçlara, aracılara ihtiyaç duymaktadır.

Yönetim olgusunun ortaya çıktığı, iktidar ilişkilerinin yaşandığı her yerde rızanın, toplumsal meşruiyetin nasıl elde edileceği, hegemonyanın nasıl sağlanacağı, iktidar alanının nasıl genişletileceği temel bir sorun olarak ortaya çıkmaktadır (Biber ve Turancı, 2014, s. 28). Toplumsal düzlemde varlık gösteren siyasal iktidarlar, yönetmiş olduğu toplumdan rıza almak zorundadır (Satır, 2018, s. 116). Toplumsal rıza hem güç eşitsizliğine güvenlik hem siyasal iktidarın egemenliğine doğallık hem de siyasal iktidarın olmazsa olmazı olan süreklilik ilkesine geçerlilik kazandırmaktadır (Çetin, 2003, s. 84). 
İktidar, "egemen bir sınıf veya fraksiyonun, iktidar ittifakının öteki üyeleri üzerinde ayrı bir egemenlik dayatması ölçüsünde, kısaca onlar üzerinde hegemonyasını kurup, onları kendi koruyuculuğu altında birleştirdiği ölçüde düzenli işlev görebilmektedir" (Poulantzas, 2004, s. 88). Bu nedenle devlet iktidarını kalıcı olarak elinde tutmak isteyen sinfflar, devletin ideolojik aygitları içinde ve üstünde kendi hegemonyasını uygulamaktadırlar (Althusser, 2014, s. 53). Kısaca bir sınıfın diğer bir sınıf üzerindeki egemenliği (Gramsci, 2007) olarak tanımlayabileceğimiz hegemonya, egemen sınıfın karşıt gruplar üzerinde kaçınılmaz olarak uygulayacağı bir zorlama anlamına da gelmektedir. Bu çerçevede iktidarın etkili olabilmesi için şiddetin de kullanabileceğini belirten Foucault (2014, s. 73-74), toplumsal rızayı da elde etmek için sadece şiddetin yeterli olamayacağını, kuşkusuz hiçbir iktidarın uygulamasında asla biri ya da diğeri olmadan, çoğunlukla aynı anda her ikisi birden olmadan gerçekleşmeyeceğini belirtmektedir. Hegemonyanun "egemen ideoloji aktarımı, bilinç biçimlendirmesi ve sosyal iktidar deneyimi aracılığ ile işleyen bir süreç" (Lull, 2001, s. 19) olması, egemen sınıf ile iş birliği yapmaya razı olan ve bu tutumuna etkinlik kazandırılması söz konusu olan müttefiklerinin fikir ve kültür alanında yönetilmesini de beraberinde getirmektedir (Gramsci, 2007).

Marx, alt sınıfın yani iş̧̧i sınıfının, kendi toplumsal deneyimlerini, toplumsal ilişkilerini ve dolayısıyla kendilerini, kendilerine ait olmayan fikirler aracılığıyla anlamaya yönlendirildiğini iddia etmektedir (Fiske, 1996, s. 221). $\mathrm{Bu}$ şekilde işçi sınıfının kendine ait olmayan fikirlerle kendini ifade etmesi sağlanarak toplumsal bir sınıfın egemene itaati garanti altına alınarak bu konudaki rızaları sağlanmaktadır. Egemenin sürekli olarak yeni algılar yaratması ve toplumların bir bilinç endüstrisinin elinde şekillenmesi nedeniyle Chomsky (2010, s. 312) de görünenin aksine bugüne kadar iktidarın hiçbir zaman halk elinde bulunmadığını belirtmektedir.

Her ne kadar farklı yöntemlerle hegemonya inşa edilebilse de hegemonyanın zaferi ve kazanılan rıza kaçınılmaz bir biçimde istikrarsızdır, asla elde bir olarak görülemez. Bu nedenle sürekli yeniden kazanmak için mücadele gerektirmekte (Fiske, 1996, s. 225), her zaman yeniden kurulmaya ihtiyaç duymaktadır. Bu açıdan iktidarın varlığı, sürekliliği ve dolayısıyla hegemonyanın istikrarı ancak ve ancak rızanın üretimi ile mümkündür. 


\section{Masallar, Mitler ve Soylu Yalanlar}

Modern öncesi devletlerde iktidarlar temelde meşruiyetlerini güç, baskı ve şiddete dayandırmış olsalar da yönetilenlerin rızasını kazanmak ya da en azından düzene tehdit oluşturabilecek olası isyan ve örgütlenmeleri engellemek üzere birtakım zihinsel yönetim biçimlerini kullanmışlardır. Mistik anlatılar, mucizeler, masallar, efsaneler modern öncesi dönemde iktidarların, toplumsal bilinci inşa etmek ve şekillendirmek üzere yönetim ve eğitimde sıklıkla başvurdukları söylemsel pratiklerdir.

Sözlü kültürün önemli bir parçası olan masallar gerçekliği olmayan, hayal ürünü kahramanları ve olayları içermenin yanı sıra ait oldukları toplumun ortak hafızasını ve değerlerini de yansıtmaktadırlar. Farklı kültürlerde masallar, olağanüstü bir çeşitlilik ve zenginlik gösterse de bu masalların neredeyse tamamı tekbiçimli ve birbirini tekrar eden öğelere sahiptir (Propp, 1985). Masalların pek çoğu gelecek nesiller için davranış modelleri, iyi-kötü ve doğru-yanlış üzerine toplumsal normlar, ahlaki kodlar ve toplumsal cinsiyet rolleri sunmaktadır. Yakışıklı prensin öpücügüüyle yüzyıllık uykusundan uyanan prensesi anlatan Uyuyan Güzel masalı eril toplumun değerlerine yer verirken, yoksul köy çocuğunun padişahın kızıyla evlenerek zengin olduğu Keloğlan masalı sınıflı toplum yapısına gönderme yapmaktadır. Bu açıdan masallar, egemen ideolojinin temsil edildiği ve yeniden üretildiği metinler olarak işlev görmektedirler. Kitlelerin, olayların en efsanevi ve olağanüstü kısımlarından etkilendiklerini ifade eden Le Bon'a göre (1997, s. 60-61) bu tür anlatılar, uygarlıkların asıl destekçileridir. İmajlar ve sahte olaylar, tarih boyunca gerçeklerden daha fazla hatırlanmış ve kitleler üzerinde daha etkili olmuşlardır. Çünkü sadece hayal ederek var olabilen kitleleri yine hayalleri kullanarak etkilemek, korkutmak ya da coşturmak mümkündür.

Toplum ve devlet üzerine ilk sistematik felsefeyi üretmiş olan Platon (2004, s. 64), idealize ettiği devlet modelinde yeni nesilleri egemen sisteme uyumlu bireyler olarak yetiştirmede gerçeklerden çok, yalan ve uydurma bilgilerin kullanılması gerektiğini düşünmektedir. Platon, çocukların hangi kalıba sokulmak istenirse o kalıba girebileceklerini, dolayısıyla onları yetiştirirken masalların kullanabileceğini ve masallar aracilığıyla onlara istenen şeylerin öğretebileceğini ifade etmektedir. Bu nedenle toplumsal bilincin inşası için sadece masalların içeriğini değil, aynı zamanda çocuklara masal anlatan 
masalcıları, anaları, dadıları da denetlemek gerekmektedir (Platon, 2004,s. 64):

- Güzel sözler de iki çeşittir değil mi? Gerçeğe uygun olanlar, uydurma olanlar.

- Evet.

- Yetiştirmede her ikisini de kullanacağız. Ama önce yalan ve uydurma olanları.

- Ne demek, anlamiyorum.

- Çocuklara önce masal anlatmıor muyuz? Masalda gerçeğe uygun şeyler varsa da bunlar çoğun uydurmadır. Küçükleri yetiştirirken idmandan önce masalları kullanırız.

- Öyledir.

- Işse bunun için de ben, müzik idmandan önce gelir diyordum.

- Hakliymişsin.

- Ama bilirsin ki, her işte önemli olan başlangıçtır. Hele iş genç ve körpe kimseleri yetiştirmek olunca; çünkü insanlar bu çağda yatkın olurlar, hangi kalıba sokulmak istenirse o kalıba girebilirler.

- Evet.

- Öyleyse her aklına gelenin uydurduğu masalları çocukların dinlemesi doğru mudur? İleride edinmelerini istediğimiz düşüncelere aykırı şeyleri duymalarına göz yumacak mıyız?

- Hayır

- O zaman ilk işimiz, masalcıları kollamak olacak. Masalları güzelse, bırakacağız söylesinler. Kötüyse yasak edeceğiz. Anaları, dadıları kandırıp, çocuklara yasak ettiğimiz masalları anlattırmayacağız. Çocukların bedenlerinden önce, güzel masallarla ruhlarını yoğurmalarını isteyeceğiz. Bugün anlatılan masallara gelince, çoğunu atmalı.

Masallar gibi mitler de benzer bir işleve sahiptir. Toplumda yaygin olarak bilinen ve tarihsel ya da yarı tarihsel bir inanç olarak itibar gören, toplumun temel değerlerini içeren veya simgeleyen mitler (Watt, 2014, s. xvii), ilk çağlardan beri toplumların bilinçaltını dışa vuran anlatımlardır (Fromm, 2015, s. 189). Mitlerin tamamı, yaradılışa yani başlangıca ilişkindir. Tüm uluslar için 'köken'in büyülü bir saygınlığ 1 vardır ve mitler bir halkın 'soylu kökeni'ni, 'eskiliği'ni ortaya koymaya yardımcı olarak (Eliade, 2001, s. 223-224), toplumlar için ortak bir payda üretirler. Toplumsal hafızanın ve kolektif kimliğin bir 
parçası olan mitler, toplumsal aidiyeti güçlendirmek, kitleleri bir arada tutmak ve egemen yapıya rıza göstermek noktasında oldukça işlevseldirler. Özellikle ulusların ırksal kökenine vurgu yapan milliyetçilik mitleri bu yönleriyle öne çıkmaktadırlar. Bu noktada Barthes mitlerin ana işlevinin tarihi doğallaştırmak olduğunu ifade etmektedir. Mitler, belirli bir tarihsel dönemde egemen olmayı başarmış bir toplumsal sınıfın ürünüdürler ve kendi kökenlerini, siyasal ve toplumsal boyutlarını gizemleştirirler ya da gizlerler (Fiske, 1996, s. 119). Schiller'e göre de (1993, s. 42) mitler, insanlara hükmetmek için kullanılırlar. Kültürel-enformasyonel aygıtlar tarafından yıllardır yapılmakta olduğu gibi mitler, halkın bilincine ustaca yerleştirilirse insanların manipüle edildiklerinin farkına varması neredeyse imkansızlaşır. Dolayısıyla mitlerin gücüne güç katılmış olur.

Halk kültürünün doğal bir parçası olan masallar ve mitlerden farklı olarak uydurulmuş gerçeklikler yani 'yalanlar' da yönetenlerin yönetim aracı olarak karşımıza çıkmaktadır. Platon'un, Devlet'te bahsettiği soylu yalanlar da benzer bir amaca hizmet etmektedirler. Platon'a göre (2004, s. 73) yalan söylemek tanrılar için yararsız, ama insanlar için bir ilaç gibi yararlı olabilir. Böyle bir ilaçsa hekimlerin elinde olmall, önüne gelen ona el sürmemelidir. Yalan söyleme yetkisinin sadece devleti yönetenlerde olması gerektiğini söyleyen Platon, devletin çıkarı için yönetenlerin yönetilenleri kandırmasını meşru görmekte ve yalanı bir yönetim aracı olarak değerlendirmektedir (Platon, 2004, s. 73-74):

- Öyleyse gerçekten ayrılma yetkisi yalnız devleti yönetenler de olmalıdır. Devletin yararına, düşmanlarına ya da yurttaşlarına yalan söyleyebilirler. Bunların dışında kimse böyle bir yola başvuramaz. Yönetilenin yönetene yalan söylemesi, hastanın hekime, öğrencinin öğretmene yalan söylemesi kadar ya da gemicinin kaptandan gemi ve gemicilerin durumunu gizlemesi kadar büyük, daha da büyük bir suçtur.

- Çok doğru.

- Demek yöneten, şehirde birinin yalanını yakalarsa Homeros'un dediği gibi: İster bir sanat adamı olsun ister falcı ister hekim ister doğramacı, onu cezalandıracak. Yalan devlet gemisini batıracak bir fırtınadir. 
Strauss da (1978, s. 102-103; 1996, s. 185) Platon'un soylu yalanını, devletin işleyişi ve halkın iyiliği için gerekli görmektedir. Bu bağlamda Strauss, iktidarın halkın iyiliği için yalan söyleyebileceğini belirterek, soylu yalanların toplumdaki farklı sosyal hiyerarşik yapıların kurallara ve yöneticilere itaat etmesini, böylece şehre gönülden hizmet etmesi için gerekli teşviki sağlayacağını, toplumsal tabakaları diğer bir deyişle kitleleri devlete/iktidara sadık bireyler olarak bir arada tutmanın bir yolu olarak düşünmektedir.

Orta Çağ'ın sonlarında feodalitenin çözülmesiyle ortaya çıkan mutlak monarşilerde her ne kadar idarenin tek elde toplanması ve mutlak hâkimiyet söz konusuysa da devlet iktidarının topluma dayandığı ve meşruiyetinin de toplumda aranması gerektiği fikri kabul görmeye başlamıştır. Mutlak monarşinin en önemli kuramclarından biri olan Machiavelli (1994, s. 109-110) Prens'te, insanların günün şartlarına göre bir köle gibi öylesine boyun eğmeye hazır beklediklerini belirterek, yöneticilerin her zaman aldatabilecek insanlar bulabileceğinden bahsetmiştir. Amaç, devletin birliğini sağlamak olduğundan yöneticilerin yönetenleri aldatmasında ve yalan söylemesinde herhangi bir sakınca görmeyen Machiavelli, yöneticilerin aldatmak istedikleri kişiler/kitleler için inanılacak gerekçeler bulmakta ya da kaypaklıklarını şirin göstermek için hiçbir zaman zorlanmadıklarını; bu aldatma işinde de yalanları ustaca allayıp pullamak, göz boyamayı olduğu gibi renk vermemeyi de çok iyi becermek gerekliliğini savunmuştur. Çünkü ona göre toplumsal rızanın üretilmesinde kurnazlık yaparak insanların beyinlerini uyutan yöneticiler, dürüstlüğü temel alan yöneticilere üstün gelmişlerdir.

Yine mutlak monarşi kuramclarından Hobbes'un devlet ve iktidar anlayışında da yöneticilerin yönetenlerin düşüncelerine yön vermesi ve yanıltması meşrudur. Hobbes'a göre (2017, s. 140-141), yönetilenlere hangi düşüncelerin öğretileceğine ve yönetilenlerin nasıl düşüneceğine yönetenler karar vermelidir. "Hangi görüş ve düşüncelerin barışa aykırı, hangilerinin ise uygun olduğuna ve dolayısıyla hangi durumlarda nereye kadar ve hangi insanların topluluklar karşısında konuşmalarına izin verileceğine ve yayımlanmadan önce kitaplardaki düşünceleri kimin inceleyeceğine karar verilmesi egemenliğin bir parçasıdır. Çünkü insanların eylemleri onların düşüncelerinden doğar"; barış ve uyumun sağlanması, insanların eylemlerinin ve düşüncelerinin iyi yönetilmesine bağlıdır. 


\section{Manipülasyon, Propaganda ve Kitle İletişimi}

Modern devletlerin kurulmasıyla birlikte, yönetim sisteminin yapısı gibi iktidarların halkı yönetme stratejileri de değişim göstermiştir. Modern öncesi dönemde kaynağını tanrısal güçten alan iktidarların yerine modern dönemde meşruiyetini toplumdan alan ve akılcı bir dayanak üzerine kurulu iktidarlar ortaya çıkmıştır. Yönetici sınıfın kendi iktidarını tesis edebilmesi ve koruyabilmesi için çoğunluğun rızasını kazanması ve iktidarını meşrulaştırması zorunlu hale gelmiştir. Bu süreçte iktidara yönelik rıza üretmenin, hegemonya kurmanın dahası yönetilenlerin tatlı rüyalar görebilmelerini sağlamanın yöntemleri de değişmiştir.

Modern çağın kitleleri için 'şaşkın sürü' ifadesini kullanan Lippmann (1998), kitleleri kontrolsüz ve organize olamayan bir yapı olarak nitelemiştir. Bu yapının kontrol edilme zorunluluğunu da "halk olması gereken yerde olmalı, böylece her birimiz ezilmekten ve şaşkın bir sürünün kükremesinden kurtulabiliriz" cümlesiyle ifade etmiştir. Lippmann bunu yapmanın yolu olarak 'rızanın üretimi' kavramını ortaya koymuştur. Rızanın üretimi yani zora ve baskıya başvurmadan halkın onayını alma ve tahakküm kurma noktasinda kitlelerin zihinlerinin profesyonelce yönlendirilmesi yani manipülasyon kavramı önem kazanmaktadır.

Modern propagandanın ve halkla ilişkilerin öncü isimlerinden Edward Bernays da (1936, s. 9) kitlelerin örgütlü alışkanlıklarının ve düşüncelerinin bilinçli ve akıllı manipülasyonunun, demokratik toplumların bir gereği ve önemli bir unsuru olduğu görüşündedir. Bu manipülasyon sürecini 'rnza mühendisliği' olarak isimlendiren Bernays (1947, s. 114) kitlelerin ancak ikna oldukları takdirde harekete geçirilebileceklerini ve bunun da ancak rıza mühendisliği ile başarılabileceğini ifade etmiştir (1947, s. 119).

Manipülasyon kavramına eleştirel perspektiften bakan Freire (1993, s. 148) bu kavramın, halkın sahneye çıktığı demokratik sistemlere özgü bir yöntem olarak, ihtiyaç doğrultusunda ortaya çıtığını ifade etmektedir. Tarihsel süreçte halk sahneye çkmadan önce manipülasyona gerek yoktur, çünkü baskı ile yönetme vardır. Demokratik sistemlerde ise manipülasyon, egemenliğin korunmasının temel bir aracı haline gelmiştir. Manipülasyon yoluyla egemen elitler halkı gerçek olmayan türden bir 'örgütlenme'ye yöneltebilir ve böylece kendilerini tehdit eden gerçek halk örgütlenmelerini engelleyebilirler. Freire'ye göre (1993, s. 139-140) manipülasyon, boyun eğdirme ve egemenliğin 
vazgeçilmez bir öğesidir. Egemen elitlerin/ezen sınıfın, halkı düşünemez hale gelinceye kadar uyuşturmak, kitleleri kendi amaçlarına uyumlu kılmak ve egemenliği sürdürmek için kullandıkları bir araçtır. Egemenler bu süreçte bazı mitlere başvurur ve bu mitleri kitle iletişim araçlarını kullanarak propaganda ve sloganlarla halka sunarlar. Örneğin ezme-ezilme düzeninin bir ‘özgür toplum' olduğu miti, bu düzenin insan haklarına saygı gösterdiği ve bu nedenle de saygiya değer olduğu miti, her çalışkan kişinin girişimci olabileceği miti, genel eğitim hakkı miti, insanların eşitliği miti, ezen sınıfların kahramanlığı miti, elitlerin iyilik ve cömertliği miti, egemen elitlerin halkın gelişimine katkıda bulundukları dolayısıyla halkın da minnetini elitlerin sözlerini kabul ederek ve onların safında yer alarak göstermesi gerektiği miti, isyanın Tanrı'ya karşı işlenmiş bir günah olduğu miti, özel mülkiyetin kişisel insani gelişme için temel olduğu miti, ezenlerin çalışkanlığı, ezilenlerin tembellik ve hilekarlığı miti ve nihayet, ezilenlerin doğal zayıflığı ve ezenlerin üstünlüğü miti.

Modern ve görece demokratik sistemlerde manipülasyonun en etkin yöntemlerinden biri propagandadır. Kişi, grup ya da geniş kitlelerin düşünce ya da davranışlarını, istenilen biçimde yönlendirmek ve değiştirmek amacıyla uygun araç ve teknikleri kullanarak yapılan her türlü planlı ve sistematik çabayı, en kaba ve geniş haliyle propaganda olarak adlandırmak mümkündür. Propaganda, önemli sembollerin manipülasyonu ile kolektif tutumların yönetimidir. Bazen mevcut bir tutumu pekiştirmek bazen de toplumda güven kazanmış bazı kurumlarca sosyal kontrol sağlamak amacıyla yardımcı bir enstrüman olarak kullanılmaktadır (Lasswell, 1927, s. 629; Bernays, 1936, s. 25) . Chomsky'nin ifadesiyle (1995, s. 36) "totaliter devlette sopa neyse, demokrasilerde de propaganda odur". Baskı ve şiddete dayalı tahakkümden uzaklaşan, rıza ve iknaya dayanan yönetim mekanizmasında egemen sınıfın varlığı, ancak rıza gösterilmesi durumunda meşru hale gelebilmektedir.

Propaganda temel olarak ilk toplumsal örgütlenmelerinden beri farklı şekillerde icra edilen bir manipülasyon yöntemidir. Grup içindeki ilişkilerin, iş bölümünün, hiyerarşinin ve nihai olarak yönetimin oluşturulması ve devamlılığı noktasında insanları yönlendirme, ikna etme, rızalarını kazanma çabası var olagelmiştir. Bununla beraber 20. yüzyılın başlarından itibaren kitle toplumuna geçiş ve yönetimin karmaşıklaşmasıyla popülerleşmiş ve kavramsallaştırılmıştır. Bolşevik ve Nazi propagandalarının başarısı siyasi liderlerin, 
teknokratların ve sosyal bilimcilerin dikkatlerini bu alana yöneltmiş ve propaganda, 20. yüzyıl siyasetinin alamet-i farikası haline gelmiştir.

Dünya siyasi tarihinde propaganda tekniklerini en etkili ve yoğun biçimde kullanan Adolf Hitler (2005, s. 219) 1srarlı ve ustaca yapılan bir propaganda ile millete cennetin cehennem, cehennemin de cennet olarak gösterilebileceğini savunmuştur. Hitler, propaganda bilmeyen eski Alman hükümetlerinin bu eksikliğinin Almanya için büyük zarar ve kayıplara neden olduğu görüşündedir. Ortak milli duyguların inşası için propagandanın olağanüstü bir silah olduğunu söyleyen Hitler'e göre (2005) başarılı bir propagandanın tek tek bireyleri değil, kitleleri hedeflemesi; herkesin anlayabileceği kadar sade ve basit olması, toplumun manevi değerlerine ve duygularına hitap etmesi gerekmektedir.

Propagandanın etkisiyle insanların zihinlerindeki sabit düşünceler birer değişken haline gelmiş (Lippmann, 1998, s. 248) ve zihinlerin kontrolü, teknik bir iş ya da bir tür mühendislik olarak görülmeye başlamıştır. 20. yüzyılın ilk yarısında propaganda, bir uzmanlık alanına dönüşmüş ve propagandacı, tanıtma uzmanı, halkla ilişkiler uzmanı gibi profesyoneller iktidar seçkinlerinden hemen sonraki toplumsal tabakayı oluşturmuşlardır. Kamuoyunun oluşumunu etkileyip biçimlendirmekte kullanılan bu kişi ve gruplar, iktidar seçkinlerinin yani egemen sinufların iktidarların, ideolojilerini, servetlerini ve prestijlerini sevimli ve haklı göstermekle görevlendirilmişlerdir (Mills, 1974, s. 442).

Egemen sınıfların ideolojileri ve çıkarları doğrultusunda kamuoyunun oluşturulmasını ve manipüle edilmesini sağlayan propaganda faaliyetleri, başlangiçta doğrudan ve görünür biçimde icra edilirken kitle iletişim araçlarının yaygınlaşması ve yeni iletişim olanaklarının doğmasıyla birlikte daha örtük ama çok daha etkili bir görünüm kazanmıştır. Günümüzde bütün iktidar biçimleri, kitleleri manipüle ve ikna etme, nihayetinde nza üretmede geleneksel ve yeni medya, halkla ilişkiler, reklam, tanıtım, siyasal iletişim gibi her türlü iletişimsel enstrümanı kullanmaktadırlar.

Herman ve Chomsky (1999) modern toplumlarda kitle iletişim araçlarını, iktidar sahiplerinin çıkarlarının temsil edildiği ve bu çıkarların propagandasının yapıldığı bir alan olarak görmektedirler. Özellikle kapitalist haber medyasının işleyiş̧ biçimini açıklamaya çalıştıkları ve 'Propaganda Modeli' adını 
verdikleri yaklaşıma göre modern toplumlarda servet ve iktidar sahipleri birtakım yöntemlerle ${ }^{1}$ medyada nelerin haber olacağına, hangilerininse kenara itilip önemsizleştirileceğine karar vermekte; siyasal iktidara veya özel çıkar çevrelerine, mesajlarını halka kolayca iletme imkânı tanımaktadırlar. Medyanin 'toplumsal amaci', topluma ve devlete egemen, ayricalıklı grupların ekonomik, toplumsal ve siyasal gündemlerini halka aşılamak ve bunları savunmaktır (Herman ve Chomsky, 1999, s. 100; Chomsky, 2010, s. 36). Gramsci'nin 'hegemonya' ve Althusser'in 'devletin ideolojik aygitları' kavramlarının açtığı yoldan gidildiğinde de görülür ki kitle iletişim araçları, egemen olmaya çalışan ideolojilerin mücadele alanlarından biridir. Bu mücadele anlam üretme, anlam kazanma ve bunu kamuoyuna kabul ettirme üzerinden yürütülmektedir. Kitle iletişimi, toplumsal iktidarın kurulmasına araclık eden bilginin denetimini sağlayarak toplumsal 'rıza'nın alınmasında önemli role sahiptir (Çoban, 2014, s. 28). Poulantzas da (2004, s. 349-352) Gramsci ve Althusser gibi devletin ideolojik aygıtlarını ve bu minvalde kitle iletişim araçlarını hegemonyanın örgütlenme biçimi olarak görmekte ve ideolojinin sadece düşüncede yer alan bir yaklaşım değil, 'kavramsal bir sistem' olduğu, toplumsal formasyonun pratiklerinde somutlaşarak egemen ideoloji bağlaminda temel iktidarı oluşturduğundan bahsetmektedir.

Platon'un da dediği gibi insanlar gerçekten çok, gerçek gibi görünen şeylere inanmaktadırlar. Kitle iletişim araçları da çoğu kez gerçek olmayan şeyleri gerçek gibi sunmaktadır. Medya aracılığıyla beyan edilen olguların ve açıklamaların gerçekliği üzerine olan şüpheler, kamuoyunun manipüle edilişinin kontrolsüz şekilde artması, kitle iletişiminde enformasyon devriminin aslında sanal dezenformasyon devrimi olduğunun bir göstergesidir (Virilio, 2003, s. 105). Bir enformasyon ortaya atıldığında, bu enformasyon yalanlanmadığı sürece, gerçeğe benzerdir ve aksama yerinde olmadıkça, hiçbir zaman gerçek zamanda yalanlanmayacak ve sonuçta hep güvenilir kalacaktır. Yalanlanmış olsa bile, mutlak surette yanlış olmayacak, çünkü medya tarafından güvenilir kılınacaktır. Gerçeğin tersine, güvenilirliğin sınırları yoktur, sanal olduğu için, kendi kendini çürütememektedir (Baudrillard, 2001, s. 72). Kitle iletişim araçları kendi ürettikleri yapay dünyayı, gerçekmiş gibi sunarak

\footnotetext{
1 'Haber eleme süzgeci' olarak adlandırdıkları bu yöntemler şunlardır: 1. Medyanın Büyüklügü̈, Mülkiyeti ve Kâr Amaçıı Oluşu, 2. Reklamcılık Ruhsatı 3. Medyanın Haber Kaynakları, 4. Tepki Üretimi ve Yaptırımcı Kurumlar, 5. Bir Denetim Mekanizması Olarak Anti-Komünizm (Herman ve Chomsky, 1999).
} 
usavurumdan giderek uzaklaştırdığı kitle içindeki bireyi her türlü etkiye, özellikle propaganda yolu ile aktarılan ideolojiye açık hale getirmektedir. Kitle iletişim araçlarının bu amaçla oluşturduğu yapay gerçeklik, gerçek olmayanı da olmuş gibi sunabilmektedir (Akarcalı, 1997, s. 69).

İlkel toplumlarda mitlerin gördüğü işlevi, modern kapitalist toplumlarda kitle iletişim araçları görmekte (Fiske, 1996, s. 162; Kaplan, 1991, s. 130); kitle iletişim araçlarıyla üretilen ve yayılan modern mitler, egemen sınıfların çıkarlarını doğallaştırmaktadır. Bu açıdan modern kapitalist toplumlarda mitlerle gerçekliğin siyasal inşası arasında karşılıklı bir ilişki söz konusudur. Bireyler, mitlerin içindeki birbiriyle ilişkili kavramların anlamının farkında olsalar bile mitsel niteliğinden haberdar değillerdir, çünkü mit kendi işleyişini gizlemektedir (Barthes, 1990). Mitler, bilincimizin gözle görünmez olan derinliklerine gömülmüş bir düşünce biçimidir. Mesela günümüzde televizyon, mitlerinkine benzer bir yol izlemektedir. Televizyon cihazı artık bizi büyülememekte ya da zihnimizi allak bullak etmemektedir. Artık televizyonun ilginç yönlerine ilişkin hikâyeler anlatmıyoruz. Televizyon cihazlarını artık özel odalarla sınırlamıoruz. Televizyonda izlediklerimizin gerçekliğinden kuşkuya düşmüyoruz ve televizyonun sunduğu bakış açısının özelliğini fark etmiyoruz. Dahası televizyonun bizi nasıl etkilediği sorusunu bile sormuyoruz. Bu soru, bazılarımıza sanki kulağımız ya da gözümüz olmasının bizi nasıl etkilediğini soruyormuş gibi acayip görünebiliyor (Postman, 2004, s. 92).

Schiller (1993) modern kapitalist sistemde kitle iletişim araçları tarafından üretilen mitler yoluyla zihinlerin kontrol edildiğini ve topluma 'paketlenmiş bilinç' sunulduğunu ifade etmektedir. Schiller' in 'bireyselcilik ve kişisel tercih miti', 'yansızlık miti', 'değişmeyen insan tabiatı miti', 'toplumsal çatışmanın mevcut olmadığı miti ve 'medya pluralizmi miti' şeklinde isimlendirdiği bu mitler siyasal, ekonomik ve toplumsal sisteme dair bireylerin zihinlerindeki belirlenimleri paket halinde sunmakta ve bunlar sorgulanmaksızın kabul edilmektedir.

Kurgulanmış gerçeklikler ve sahte öykülerle büyüklere masallar anlatan ve modern mitler yaratan kitle iletişim araçları, egemen ideolojilerin propagandasını yaparak egemen sınıfların iktidarının tesis edilmesinde ve yeniden üretilmesinde temel aygıtlarından biri haline gelmiştir. Başta haberler ve reklamlar olmak üzere ana akım medya içerikleri ile demokrasi, çoğulculuk, toplumsal uzlaşı, bireysel özgürlük, modern bilim, teknoloji, zenginlik, başarı, profesyonellik, güzellik, kusursuzluk, erillik, dişilik gibi modern kapitalist 
sistemin hâkim değerleri mitleştirilmektedir. Barthes'in (1990) de ifade ettiği gibi bu mitler egemen sınıfların çıkarlarını doğallaştırmakta ve bu sınıfların iktidarını meşrulaştırmaktadır.

\section{Sonuç}

Siyaset bilimi, sosyoloji, felsefe, hukuk gibi alanların tartışmalı konularından biri olan iktidar kavramı, emretme ve yönetme gücünün yanı sıra emretme ve yönetme hakkına sahip olmayı da içeren; bu anlamda güç ve rızanın birlikteliğinden oluşan bir olgudur. Dolayısıyla iktidar konusu çoğunlukla meşruiyet kavramıyla birlikte ele alınmış; iktidarın kaynağını nereden aldığı ya da diğerlerini ne adına yönettiği, iktidara ilişkin temel sorulardan biri olmuştur. Tarihsel süreçte bütün iktidar biçimleri, iktidarı ellerinde tutmak ve bunun sürekliliğini sağlamak adına verdikleri mücadelede meşru bir zemine dayanma ve yönetilenlerin rızasını kazanma ihtiyacı duymuşlardır. İnsanlık tarihi boyunca iktidarlar, meşruiyetlerini inşa etmek ve yönetilenlerin rızasını kazanmak adına farklı yöntem ve tekniklere başvurmuşlardır. Aynı zamanda toplumsal bilincin ve -zihinleri yönlendirmek suretiyle- hegemonyanın inşasına da hizmet eden bu yöntem ve teknikler, zaman içinde dönüşmüş ve biçim değiştirmiş olsalar da temelde aynı amaca hizmet etmişlerdir.

Modern öncesi toplumlarda meşruiyetini tanrısal güçten alan iktidarlar toplumsal bilinci inşa etmek ve zihinleri yönlendirmek adına masallardan ve mitlerden yararlanmışlardır. İnsanlığın ilkel düşünüşünün bir ürünü olarak ortaya çıan ve halk kültürünün de önemli bir parçası olan bu sözlü metinler, iktidarı, iktidarın eylemlerini, bu eylemlerin sonuçlarını ve ortaya çıkan egemenlik alanını doğallaştırma ve meşrulaştırma işlevlerini de yerine getirmektedirler. İçinde oluştukları kültürün ve dönemin ırk, soy ve güç temelindeki iktidar ilişkilerinin taşıyıcılığını ve savunuculuğunu yapan bu metinler, yönetilenlerin gündelik hayatta nasıl davranmaları gerektiğine dair dini, toplumsal ve kültürel kodları da barındırarak toplumsal bilincin inşasında önemli rol üstlenmekte; yönetilenler açısından makbul/kabul edilebilir yurttaşın nasıl olması gerektiği ve iktidara itaat biçimlerinin neler olduğunu içermektedirler. Ayrıca modern öncesi dönemde iktidarların sistematik ve bilinçli olarak ürettikleri yalanlar da yönetme sanatının doğal bir parçası olarak değerlendirilmiş ve halkın yararına söylenen yalanlar meşru ve ahlaki kabul edilmiştir. Bu çerçeveden bakıldığında toplumsal bilincin inşası ve rızanın 
imalatına yönelik manipülasyon faaliyetlerinin ortaya çıkışına ilişkin sanayi devrimi sonrasını ve özellikle 20. yüzyılı işaret eden yaklaşımların aksine yönetilenleri manipüle etmenin, kitleleri ikna etme yoluyla iktidara ve sisteme meşruiyet kazandırmanın her dönemde iktidarların önceliği olduğunu söylemek yanlış olmayacaktır.

Modern dönemde ise söz konusu masalların, mitlerin ve soylu yalanların yerini medya metinlerindeki kurgulanmış gerçeklikler ve sahte öyküler almıştır. Görece gelişmiş modern kapitalist toplumlarda demokrasi ve çoğulculuğun özümsenmiş olması nedeniyle iktidarlar tarafından uygulanan şiddete ve baskıya karşı çıkma ve direnme gibi toplumsal refleksler gelişmiştir. Meşruiyetini halk egemenliğine dayandıran modern iktidarlar için halkın onayını almak ve rızasını kazanmak zorunluluk halini almıştır. Başta siyasal iktidarlar olmak üzere modern toplumlardaki farklı iktidar odakları toplumsal kabulü ve rızayı üretebilmek ve de sürdürebilmek adına toplumsal bilinci inşa etmek ve zihinleri manipüle etmek için kitle iletişim araçlarından etkin bir şekilde faydalanmışlardır. Modern öncesi dönemde masalları ve mitleri yayan masalclar, ozanlar ve destancların yerini modern kapitalist toplumlarda kitle iletişim araçları almıştır. Modern ya da teknolojik masalcılar olarak adlandırabileceğimiz kitle iletişim araçları modern masalların ve mitlerin hem üreticisi hem de dağıtıcısı konumundadırlar. Söz konusu modern masallar ve mitler çoğu zaman 'gerçeklik' iddiasıyla sunulmakta, iktidarın yapısı ve sistemin doğası maskelenmektedir. Bu çerçevede başta haberler ve reklamlar olmak üzere gerek geleneksel gerekse yeni medya ortamlarında üretilen içeriklerle toplumsal, kültürel ve siyasal iktidarı elinde bulunduran egemen sınıfların değerleri ve çıkarları meşrulaştırılmakta, toplumsal bilincin inşası ve rızanın imalatıyla iktidarın varlığı sürekli ve değişmez hale gelmektedir. 
EXTENDED ABSTRACT

\title{
Legitimacy of Power and Consent Manufacturing: Construction of Social Consciousness From Tales and Myths to Mass Communication
}

\author{
Ahmet Öztekin - Hülya Öztekin \\ Erciyes University, Faculty of Communication
}

The socialization and politicization process of humanity has led to the emergence of organized political structures that have become institutionalized over time and revealed the distinction between ruler and ruled. Even though this distinction has shown differences changing in accordance with related social structure and period, the 'power struggles', the only constant of this multivariate structure, have continued in different ways throughout history.

The power struggle is not something which is attempted only once for coming to power. This struggle is a cyclical process requiring indefinite number of attempts which is involved in for maintaining and protecting power until it is lost, which is repeated for regaining power when it is lost. To come to power or to protect present power depends on obtaining the consent of the ruled. With the first social structures, the continuous observation of masses by rulers, and trust and consent of masses to power created an important management problem. For this reason, the effort of the power to manipulate the masses, emerging as a result of desire to govern combined with power is as old as the history of power and is discussed as much as the power.

Due to the power of the masses, they have always been considered a potential threat by powers, thus controlling and convincing masses have been among the primary goals of political powers. The powers emerging as an instrumentalized appearance of social culture expect all member of societies to obey them. The basic goal of this control on the masses is to provide the control and obedience of them. For this reason, all political systems, including democracy, are established on ensuring the obedience of individuals and manipulating the masses accordingly. 
This study aimed to reveal different methods used by the powers throughout the history to construct the social consciousness and to manufacture consent under the power and power relations in social and political life. In this regard, this study focused on the historical evolution of hegemony and consent manufacturing tools used by the powers from primitive communities to today's modern capitalist societies and discussed the relationship between mass media, which are the functional counterparts of tales, myths, legends and noble lies used as a means of manufacture of hegemony and consent in pre-modern societies.

The powers, legitimised by divine power in the pre-modern societies, have used tales and myths in order to construct social consciousness and to direct minds. These oral texts, emerging as a product of the primitive thinking of humanity and are an important part of folk culture, also fulfil the functions of normalising and legitimizing the power, the actions of power, the results of these actions and the emerging domain of sovereignty. These texts, defending and transferring the power relations based on race, ancestry and power of the culture and period in which they have been established, play an important role in the construction of social consciousness by referencing to religious, social and cultural codes regarding how the ruled should behave in daily life, and identify how a reasonable/acceptable citizen should be in terms of the ruled and what types of obedience to power are.

In addition, the lies generated by the powers systematically and consciously in the pre-modern period have been considered a natural part of the art of administration, and the lies told for the benefit of people have been accepted to be right and ethical. In this perspective, it will be right to express that manipulating the ruled, legitimizing the power and the system by convincing the masses is always a priority of governments in all periods contrary to the approaches arguing that the period following the industrial revolution and especially the $20^{\text {th }}$ century are the periods when the manipulation activities related the construction of social consciousness and the consent manufacturing emerged.

In the modern period, these tales, myths and noble lies have been replaced by fictionalized realities and fake stories in media texts. As democracy and pluralism are internalised in the relatively developed modern capitalist societies, the social reflexes, such as opposing and resisting to violence and oppression imposed by governments have developed. It is necessary for the 
modern powers taking their legitimisation from popular sovereignty to receive approval and consent of the people. Different power centres in modern societies, especially political powers have benefited from mass media effectively in order to manufacture and to maintain social obedience and consent as well as to construct social consciousness and to manipulate minds. The storytellers, bards and legend tellers spreading tales and myths in the pre-modern period have been replaced by the mass media in the modern capitalist societies. The mass media that can be named after modern or technological storytellers are both producer and teller of modern tales and myths. These modern tales and myths are mostly provided with a claim of 'reality', thus the structure of power and the nature of system are covered with a mask. In this respect, the values and interests of the dominant classes with social, cultural and political powers are legitimized by with content produced in both traditional and new media, especially news and advertisements, and the presence of power becomes permanent and constant by means of the construction of social consciousness and the consent manufacturing.

\section{Kaynakça / References}

Akarcall, S. (1997). Uluslararast iletişimde propaganda ve ideoloji. Ankara: Ankara Üniversitesi lletişim Fakültesi Yayınları.

Althusser, L. (2014). İdeoloji ve devletin ideolojik aygıtları. (A. Tümertekin, Çev.). İstanbul: İthaki Yayınları.

Arendt, H. (1994). İnsanlik durumu. (B. S. Şener, Çev.) İstanbul: İetişim Yayınları.

Barthes, R. (1990). Çağdaş söylenler. (T. Yücel, Çev.). İstanbul: Hürriyet Vakfı Yayınları. Baudrillard, J. (2001). Tam ekran. (B. Gülmez, Çev.). İstanbul: Yapı Kredi Yayınları.

Bernays, E. L. (1936). Propaganda. New York: Liveright Publishing Corporation.

Bernays, E. L. (1947). The engineering of consent. The ANNALS of the American Academy of Political and Social Science, 250 (1), 113-120.

Biber, A. ve Turancı E. (2014). Toplumsal şeytan üçgeni: İktidar, hegemonya ve propaganda. Akdeniz Üniversitesi İletişim Fakültesi Dergisi, 21, 28-41. DOI: 10.31123/akil.442999

Canetti, E. (2006). Kitle ve iktidar. (G. Aygen, Çev.). İstanbul: Ayrınt Yayınları.

Chomsky, N. (1995). Medya denetimi. (Ş. Süer, Çev.). İstanbul: Tümzamanlar Yayınclik.

Chomsky, N. (2010). İktidar anlamak. (P. R. Mitchell ve J. Schoeffel, Ed.). İstanbul: Bgst Yayınları. 
Çetin, H. (2003). Siyasetin evrensel sorunu: İktidarın meşruiyeti-meşruiyetin iktidarı. Ankara Üniversitesi SBF Dergisi, 58(3), 61-88.

Çoban, S. (2014). Medya ve iktidar-hegemonya, statüko, direniş. E. Arsan veS. Çoban (Haz.), Iktidarm Medyası içinde (s. 27-52). İstanbul: Ezgi Matbaa.

Duverger, M. (1964). Politikaya giriş. (S. Tiryakioğlu, Çev.). İstanbul: Varlık Yayınları. Duverger, M. (1982). Siyaset sosyolojisi. (Ş. Tekeli, Çev.). İstanbul: Varlık Yayınları. Eliade, M. (2001). Mitlerin kökenleri. (S. Rifat, Çev.). İstanbul: Om Yayınevi. Fiske, J. (1996). İletişim çalışmalarına giriş. (S. İrvan, Çev.). Ankara: Ark Yayınları. Foucault, M. (2007). İktidarnn gözü. (I. Ergüden, Çev.). İstanbul: Ayrıntı Yayınları. Foucault, M. (2014). Özne ve iktidar. (I. Ergüden ve O. Akınhay, Çev.). İstanbul: Ayrınt Yayınları.

Freire, P. (1993). Pedagogy of the oppressed, New York: The Continuum International Publishing Group.

Fromm, E. (2015). Rüyalar, masallar, mitler. (A. Arıtan ve K. H. Ökten, Çev.). İstanbul: Say Yayınları.

Gramsci, A. (2008). Hapishane defterleri. (K. Somer, Çev.). Ankara: Aşina Kitaplar.

Herman, E. S. ve Chomsky, N. (1999). Medya halka nasil evet dedirtir. (I. Kaplan, Yay. Haz.). İstanbul: Minerva Yayınları.

Hitler, A. (2005). Kavgam. (H. C. Yalçın, Çev.). İstanbul: Manifesto Kitapları. Hobbes, T. (2017). Leviathan. (S. Lin, Çev.). İstanbul: Yapı Kredi Yayınları.

Kapani, M. (1998). Politika bilimine giriş. Ankara: Bilgi Yayınevi.

Kaplan, Y. (1991). Öykü anlatma ve mit üretme aracı olarak televizyon. Y. Kaplan (Der.), Enformasyon Devrimi Efsanesi içinde (s. 115-139). Kayseri: Rey Yayınları.

Kışlalı, A. T. (1997). Siyaset bilimi. Ankara: İmge Kitabevi.

Lasswell, H. D. (1927). The theory of political propaganda. The American Political Science Review, 21(3), 627-631, https://www.jstor.org/stable/1945515 (14.02.2020).

Le Bon, G. (1997). Kitleler psikolojisi. (Y. Ender, Yay. Haz.). İstanbul: Hayat Yayınları.

Lippmann, W. (1998). Public opinion. New Brunswick, New Jersey: Transaction Publishers.

Lull, J. (2001). Medya iletişim kültür. (N. Güngör, Çev.). Ankara: Vadi Yayınları.

Machiavelli, N. (1994). Prens. (N. Güvenç, Çev.). İstanbul: Anahtar Yayınları.

Marx, K. (2009a). Louis Bonaparte'ın 18 Brumaire'í. (E. Özalp, Çev.). İstanbul: Yazılama Yayınları.

Marx, K. (2009b). Fransa'da sını mücadeleleri 1848-1850. (E. Özalp, Çev.). İstanbul: Yazilama Yayınları.

Mills, W. (1974). İktidar seçkinleri. (Ü. Oskay, Çev.). Ankara: Bilgi Yayınevi. 
Nye, J. S. (1990). The changing nature of world power. Political Science Quarterly, 105 (2), 177-192.

Platon (2004). Devlet. (S. Eyuboğlu ve M. A. Cimcoz, Çev.). İstanbul: Türkiye İş Bankası Kültür Yayınları.

Postman, N. (2004). Televizyon öldüren eğlence. (O. Akınhay, Çev.). İstanbul: Ayrıntı Yayınları.

Poulantzas, N. (2004). Faşizm ve diktatörlük. (A. İnsel, Çev.). İstanbul: İletişim Yayınları. Propp, V. (1985). Masalın biçimbilimi. (M. Rifat ve S. Rifat, Çev.). İstanbul: Bilim/Felsefe/Sanat Yayınları.

Rousseau, J. J. (2005). Toplum sözleşmesi. (T. Ilgaz, Çev.). Ankara: Paragraf Yayınevi.

Russell, B. (2003). İktidar. (E. Esençay, Çev.). İzmir: İlya Yayınevi.

Satır, M. E. (2018). Siyasal meşruiyetin sağlanmasında medyanın rolü üzerine bir değerlendirme. Türkiye İletişim Araştırmaları Dergisi, 30, 115-128. DOI: 10.17829/turcom.457154

Schiller, H. (1993). Zihin yönlendirenler. (C. Cerit, Çev.). İstanbul: Pınar Yayınları.

Sennett, R. (2005). Otorite. (K. Durand, Çev.). İstanbul: Ayrıntı Yayınları.

Strauss, L. (1978). The city and man. Chicago \& London: The University of Chicago Press.

Strauss, L. (1996). The origins of political science and the problem of Socrates. Interpretation, 23 (2), 127-207.

Thompson, B. J. (2008). Medya ve modernite (S. Öztürk, Çev.). İstanbul: Kırmızı Yayınları.

Virilio, P. (2003). Enformasyon bombası. (K. Şahin, Çev.). İstanbul: Metis Yayınları.

Watt, I. (2014). Modern bireyciliğin mitleri. (M. Doğan, Çev.). İstanbul: Boğaziçi Üniversitesi Yayınevi.

Weber, M. (2008). Bürokrasi ve otorite. (H. B. Akın, Çev.). Ankara: Adres Yayınları.

Weber, M. (2012). Ekonomi ve toplum (Cilt. 2). (L. Boyac, Çev.). İstanbul: Yarın Yayınları.

\section{Kaynakça Bilgisi / Citation Information}

Öztekin. A. ve Öztekin, H. (2020). İktidarın meşruiyeti ve rıza üretimi: Masallardan ve mitlerden kitle iletişimine toplumsal bilincin inşası. OPUS-Uluslararası Toplum Araştırmaları Dergisi, 16(30), 29112940. DOI: $10.26466 /$ opus.758822 